\title{
Stories of Learning: A Case Study of Norwegian Plumbers and Apprentices in TVET at the Construction Site and in a Training Agency
}

\author{
Marit Lensjø \\ Oslo Metropolitan University, P.O.Box 4, St. Olavs plass, 0130 Oslo, Norway
}

Received: 20.07.2019, Accepted: 05.02.2020, Published: 22.07.2020

\begin{abstract}
Context: Through a dual model, based on 2 years of education in upper secondary school followed by two and a half year of apprenticeship training, Norwegian plumbing education has become an integrated part of the Technical Vocational Education and Training (TVET). Competence and skills are described in national plumbing curriculum. However, there is little information on how learning and training, interaction and relations between craftsmen and apprentices take place and develops at the workplace. The objective of this article is to identify significant learning processes by studying apprentices in a training agency and in communities of plumbers at the building site.
\end{abstract}

Approach: The study has an ethnographic approach, based on a combination of fieldwork and interviews with apprentices, plumbers and a vocational teacher. During one year of fieldwork I followed a group of plumbing apprentices in a training agency, and in their plumbing companies at different construction sites. As a former plumber and vocational teacher, I was able to participate as a plumber and researcher and thus I had a unique position to work along with the apprentices and plumbers. This enabled me to observe interaction, learning and training in their communities of practices as an insider.

Findings: The study showed that the process of learning practical skills, a professional language and a technical rationale was time consuming, challenging and sometimes tiering. In return the apprentices discovered proficiency, gained confidence and were considered as

${ }^{*}$ Corresponding author: marlen@oslomet.no 
participants in the community of plumbers. A central finding is the great value of working in a community of plumbers at the building site, combined by studying sanitary and heating technology at the training agency. Among peers at the training agency, the apprentices were challenged to build and explore complex pipe laying, and to discuss technical regulations and rationale with each other and the vocational teacher.

Conclusion: Craftsmen, like plumbers, consecutively handle a variety of technical work tasks and situations. Inside practice, the plumbers are close to materials and systems on construction site, where pipes, cableways and building structures looks different from the plan and the progress on paper. As experts, the plumbers often solve problems more functional and cost effective than suggested in the blueprint. The study shows how apprentices and plumbers develop skills, tacit knowledge and professionality through involvement with relevant things and situations, and by sharing experiences and technical expertise in communities of peers and plumbers.

Keywords: Training Enterprise, Training Agency, Apprenticeship, Body and Senses, Inside and Outside Practice, Tacit Knowledge, Drawing and Storytelling, Vocational Education and Training, VET

\section{Introduction}

Craftmanship has a long tradition of learning in the world of work. Working alongside skilled workers, apprentices participate in the daily work. Through having active positions inside the professional community of practice, the apprentices talk, watch, and listen to skilled craftsmen, become familiar with tasks, tools and materials, and gradually become skilled workers (Eikeland, 2015). In Norway, apprentices in crafts such as plumbing, attend a training agency specially designed for the plumbing profession.

In this article, I study interaction and learning processes in communities of apprentices and plumbers in Norwegian training enterprises on construction sites and in a training agency. Interaction and communication among the craftsmen, the company manager, and the architect are pivotal to ensuring a high quality of work and progress, of procurement, and of management of supplies and equipment. Learning and training at the workplace are analysed in the language of situated learning theories and social-constructive perspectives (Brown et al., 1989; Dewey, 1916; Illeris, 2006, 2015; Lave \& Wenger, 1991; Merleau-Ponty, 2002; Wenger, 1998).

As a researcher with a background as a former apprentice, plumber, plumbing engineer and vocational teacher, I am confronted with my personal experiences in all levels of this study. Hence, I have worked deliberately to balance distance and proximity to my informants, during the data collection and through the analysis. The study has a qualitative approach, and 
the empirical findings build upon rich field notes from one year of participating observations in one training agency and at three construction sites, dialogue, group interviews with two communities of plumbers, and in-depth interviews with nine apprentices, two plumbers and one vocational teacher in a training agency.

After an introduction to the study, I present the Norwegian context and the theoretical framework, followed by the research context and method. I then present the findings and discuss how the apprentices learn to be plumbers through interaction and communication with relevant things and comprehensive work tasks, and how they construct understanding of plumbing and a professional language through interaction and communication with plumbers, their peers, and the vocational teacher at the training agency. Furthermore, the analysis shows that responsibility, professional knowledge, and autonomy are strong incentives for plumber's involvement and problem-solving at work. The findings show how experienced plumbers obtain and share rich data through vocational storytelling and how they use experiential learning to perform comparative analyses of "situated" (former and current) problems at the construction site.

\section{Plumbing Education and TVET in Norway}

The Norwegian TVET model entails two years of education in upper secondary school followed by two years of apprenticeship training. The $(2+2)$ dual model was established in 1994 and consisted of a large number of general subjects, a one-year basic vocational course followed by a one-year specialisation in upper secondary school. Under the reform "Knowledge Promotion Reform" in 2006, the second year of plumbing was replaced by a broader twoyear programme in building and construction. Vocational training in plumbing is provided mainly during the apprenticeship period, although the apprenticeship period was shortened under the Reform94. In 2008, following extensive pressure from the plumbing industry, the education authorities agreed to extend the apprenticeship for plumbers to $2 \frac{1}{2}$ years, and in the new VET curricula to be implemented in the school year 2020/21, specialisation in plumbing will be reintroduced as a second-year course in upper secondary school.

To maintain the level of the journeyman's certificate most of the Norwegian plumbing companies cooperate with a training agency. Training agencies are often run by a vocational pedagogical staff who follow the apprentice and share the responsibility for training of the apprentices with the training enterprises (Nore, 2015). At the training agency in plumbing, the apprentices are trained in technical drawing, sanitary and heating technology and practical tasks - normally for one day a week in the final year of their apprenticeship period. A Norwegian training agency is a private enterprise representing several member companies. Public funds, following the apprenticeship contract, are used to finance the operation of the training agency (Norwegian Directorate for Education and Training, 2020). An elected 
board, representing the member companies and the training agency, decides how the funds are to be used and how to organise the training agency. In this study I focus on apprentices and plumbers, learning and training processes in training enterprises and on a training agency during the work-based part of the TVET dual-model.

\section{Social-Constructivism and Situated, Work-Based Learning}

The nature and meaning of the work environment has always been essential to becoming a craftsman. The craftsman's work and learning environment consist of materials and tools, the location and task, - and most importantly, the social and professional environment of skilled workers in the community of practice (Lave \& Wenger, 1991). Although learning often takes place while tasks are being performed, it does not look as if much teaching is going on. In fact, teaching very rarely occurs as an identifiable activity; instructions or explanations are communicated -while plumbers and apprentices perform their tasks (Jordan, 1989). The properties of things, such as the size and shape of a pump, its weight, surface, sound, colour and temperature, present variations of phenomena that become meaningful through engagement in the work task, such as laying pipes. In order to perceive things, Merleau-Ponty points out that "we need to live them" (Merleau-Ponty, 2002, p. 379). When we are in touch with things, our perceptions are immediately "translated" to our body. When our senses detect a scent, a breeze or a taste, it is sometimes difficult to explain what we perceive in words, but through our senses we can recognise specific details, a face or a situation. According to MerleauPonty, this is based on an implicit understanding that the body's consciousness perceives the symbolism in the thing and links each sensory quality to the rest of the body, including experiences already perceived (Merleau-Ponty, 1994). Technical crafts like plumbing always depend on things, and often it is in the craftsman's hands, before his or her eyes, that a things' potential and limitations emerge (Merleau-Ponty, 2002; Tesfaye, 2013).

Merleau-Ponty's phenomenology and his understanding of subjectivity lead in many ways to Dewey's (1916) experience and enquiry-based approach to learning (Gibson, 2016). Like Merleau-Ponty, Dewey values the knowledge of "how to do": "How to walk, talk, read, write, skate, ride a bicycle, manage a machine, calculate, drive a horse, sell goods, manage people and so on indefinitely" (Dewey, 1916, p. 201). All these examples of action skills are acquired through hours, sometimes years of training and practice, and contain embodied, tacit knowledge which is often hard to describe or to identify as explicit knowledge. Similarly, the tacit communication between the craftsman and the thing, are often difficult to explain in words. Gamble's (2001) study of cabinet makers shows how apprentices communicate and develop tacit knowledge while engaged in intensive woodworking, most of the time without any corrections from the master-trainer. Explanations about the construction, such as to "foresee or understand" a requested angle or a specific shape in the piece of wood, were visualised by 
drawings and rough sketches referred to as a "third language", while at the same time the master-trainer encouraged the apprentices to think and visualise while working. As an "outsider", Gamble (2001) experienced how difficult it was to understand how the master-trainer and the drawing teacher communicated with the apprentices simply by setting the task, checking the apprentices' drawings, and showing them where they had gone wrong and how to fix it: "It took the observer a long time to work out that what she was observing was tacit transmission of the capability to 'see' what is there and what is not there" (Gamble, 2001, p. 188).

As an aspect of social practice, the apprentices involve their whole person in the social community and in its wide systems of meaningful relations. These specific systems of relations occur, reproduce, and develop in social communities, which means the relations not only define learning a craft, but also construct an identity (Lave \& Wenger, 1991). When Schön (2009) argues that "our knowledge is in our actions", he refers to how our senses and behaviour respond to the situations and the materials we deal with in everyday life. From my experience as plumber, I know that from a bundle of pipes the plumber builds a pipe system based on principles and functions in the heating system, where the water, temperature, and pressure set the rules. The plumber makes sure the pipe dimensions match the heat demand of the radiators and builds the pipe system to make sure the exact amount of hot water can circulate and accomplish its mission. While he builds the pipe system in symmetric and parallel lines he makes threads and bends, and splits the pipes as the courses divide, avoiding possible traps that would impede flow, and making smooth connections to each functioning heating system. A plumber's work is based on the customer's specification. However, plumbing depends upon disciplines and rationales, such as tables, formulae, calculations, standards and regulations, as well as centuries of technical practice, testing and situated experienced knowledge within the world of plumbing. For every movement, there is an explanation for acting like this - and not like that.

Through years of practice, craftsmen's expertise contains an infinite amount of embodied experience that is woven into senses, the intellect, or into the dexterity of the fingers and hands, a tacit knowledge that can only be rendered visible through practical work (Polany, 1966). Whether it be mathematics, manual dexterity or professional knowledge, the plumber uses embodied knowledge in every action, small or large (Dewey, 1916; Lensjø, 2017; Merleau-Ponty, 1994; Sennett, 2009). Illeris $(2006,2015)$ argues that all learning is situated; not only the interaction between human beings but also the context they create and the work they produce. In addition, the utility and purpose of every tool are invented by human beings and are the result of their ideas for use, meaning that it is impossible to understand any kind of interaction with the material world differently from interaction with the social world. However, becoming a competent plumber takes more than just being part of an environment. Illeris $(2006,2015)$ argues that learning implies two very different processes: External interaction between the learning and the person's social, cultural, and material envi- 
ronments, and an internal psychological process of elaboration and acquisition (Illeris, 2006, 2015). Through situated learning in a community of practice, apprentices gradually acquire skills and knowledge about their new world (Dewey, 1916; Dreyfus \& Dreyfus, 2012; Lave \& Wenger, 1991; Wenger, 1998).

One way to understand situated learning in the workplace is as a fostering process, where the purpose is to continue a certain profession. That is, to understand situated learning means that what you learn belongs in a specific context. Brown et al. $(1989, \mathrm{p} .4)$ explain this in a simple way: "It is quite possible to acquire a tool but to be unable to use it." The understanding of how to use plumber's tools to build a pipe system reflects the cumulative wisdom of the culture in which the tool is used and where the meaning is a product of negotiation within a culture and of practice in authentic activity (Brown et al., 1989). Empirical studies of situated learning emphasise the importance of knowing the history and cultural conditions of the profession as well as the rationale behind the work task. Lave and Wenger (1991) draw a distinction between talking about the vocation from the outside and being inside a community of practice. Talking about the vocation from the outside refers to a more general form of teaching the vocation, such as in school. Talking about the vocation from the inside refers to interaction in a community of practice where reflection-in action and reflection-on-action is crucial to understanding and using materials and equipment, progress and physical settings (Schön, 2009; Wenger, 1998).

\section{Research, in the Context of Interaction and Communication at the Workplace}

Learning potential at the workplace is broadly presented in the comprehensive studies of Stephen Billett (2001, 2006, 2008, 2014, 2016). According to Billett, occupational practices are not wholly subject to the actions of others but arise "through individual's thinking and acting and mediation of what they experience" (Billett, 2016, p. 615). A central premise is that no distinctions are made between doing, learning and the remaking of (i.e. occupational) practice (Billett, 2014). Practice within an everyday occupational practice setting leads to rehearsal, refinement of procedures, and close guidance from other practitioners and experts (Billett, 2001). Furthermore, when individuals think and act in and through engagement in their work, they can utilise what they know, what they can do, and what they value, and thereby not only remake but transform their occupational practices (Billett, 2016). Based on such a view of individual learning, Billett argues that learning is deeply embedded in us, based on our experiences. He argues that personal epistemologies form the basis of individuals' active knowing, engaging, and learning. These attributes are more than beliefs and extend to what individuals know and can do, including their embodied knowledge (Billett, 2016). The constant changes during the progress of work on a building site are recognisable in theories of 
situated learning and how learning at the workplace is bound to a community of practice (Lave \& Wenger, 1991; Wenger, 1998). According to Wenger et al. (2002, p. 27) a community of practice is a unique combination of three fundamental elements: "A domain of knowledge, which defines a set of issues; a community of people who care about this domain; and a shared practice that they are developing to be effective in their domain." A strong community encourages the members to share ideas, to listen carefully, and to ask difficult questions. The domain denotes the topic the community focuses on, while the practice is a set of frameworks, documents, ideas, information, tools, styles, language and stories.

Fear et al. (2003) refer to how shared stories can help the members within a community of practice to solve problems by helping them to sense an impact or to visualise (through the mind's eye) details or essential information that otherwise would be difficult to explain. Fear et al. go further and maintain that sharing a story is not only reserved for ongoing challenges, but that stories of "real people engaging in real work" also foster valuable connections between theory and practice (Fear et al., 2003). Stories are often told as the work is carried out, and Jordan (1989) point out that it should be remembered that the colleagues are experts: "Because of the way these stories were treated, elaborated, ignored, taken up, characterised as typical and so on, they contributed to understanding and solving issues in the present job" (Jordan, 1989, p. 935). Related to a specific situation, stories often contain thick descriptions about work situations and contexts. These stories are, according to Jordan: "Packages of situated knowledge, knowledge that is not available abstractly, but is called up as the characteristics of the situation require it" (Jordan, 1989, p. 935). Unlike cultures that document their knowledge in texts, oral cultures like craftsmanship store and share knowledge among the members of the community. According to Yang (2013), storytelling in oral cultures has multiple functions. In addition to sharing information and social and aesthetic pleasure, storytelling demonstrates one's competence and identity as a craftsman and reveals one's membership and status in the community (Yang, 2013).

\section{$5 \quad$ Method}

This study has an ethnographic approach, based on a combination of fieldwork and interviews with apprentices and plumbers. My own background as a plumber gave me access to the training agency and the construction sites, and was my "ticket" to participate as a professional member of the communities of practice. During my fieldwork, I followed a group of plumbing apprentices in a training agency for one year. Throughout the year, I followed two of the apprentices and their plumbing companies at different construction sites. In this article I present some of my findings from the training agency, but mainly I present findings from the largest construction site with four apartment buildings, each at a different stage in the building progress. Eleven plumbers and four apprentices worked on this site. As a member 
of the group, I had a unique position to observe interaction and communication within the group of plumbers and apprentices. Working full days alongside my informants, I was able to follow the group during their morning meetings, coffee and lunch breaks, and all kinds of plumbing processes. The question of the position of the fieldworker seems to pose a challenge in qualitative research. Field positioning is described broadly in the anthropological work of Whyte (1981) where roles and positions in clubs and gangs are characterised by predictions, informal rules and mutual balance. More obvious is the otherness and vulnerability of the fieldworker in an institutional workplace like a health institution or a construction site, where all the workers have specific professional roles and positions. According to Van der Geest and Sarkodie (1998), qualitative researchers in an institution like a hospital or clinic find themselves out of place. Not being a doctor, nurse, other type of health worker or patient, makes their position somewhat awkward. Currently, it is more common for fieldworkers to engage in participating research, dressing like and following professionals (Agrosino \& Mays de Pères, 2000; Hastrup, 2010; Ringer, 2013; Wadel, 2016).

From my position as a plumber and participating researcher, I soon discovered that to do research within my own culture was easy and more practical because of my familiarity with the cultural language and the plumbing profession. Within our own culture, there exists what Giddens (1993) calls "a mutual knowledge", meaning that the researcher in many ways can take advantage of the experienced, professional and cultural knowledge he or she shares with those who are being observed (Wadel, 2016). On the other hand, as a participant in my own culture I may not be able to see what might be obvious to a stranger. Aware of the probable "blind spots" in my observations, I was still very pleased to be a part of the plumber's community of practice on the construction site. From such a position, I was able to participate in discussions about the work progress and thereby understand what specific and underlying problems the plumbers had to deal with in their everyday work life. Also, through my own work tasks I was directly confronted with the same experiences as my informants, be it a lack of important pipes or fittings or collaboration problems with other occupational groups on the construction site. Through my position as a plumber, I was a participator in real contexts and situations, and it was easier to understand the strength of the plumber's anger and frustration - such as in a specific situation where we all were "overrun" by the project manager - because I could feel the injustice myself. While working as a skilled worker in the Norwegian community of plumbers, the other workers on the site got "used to" having me around. My presence gradually became a part of the everyday life on site. From then on, I was able to study communication and cooperation from a unique inside position. 


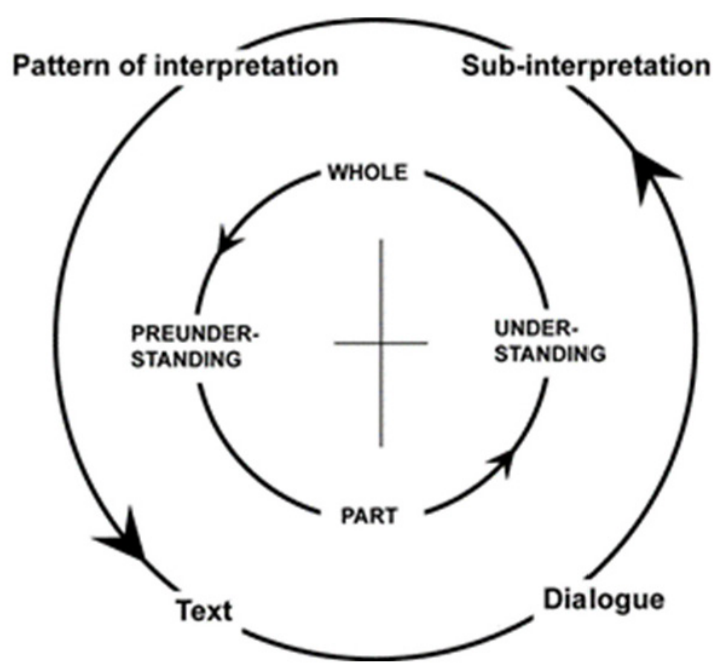

Figure 1: The hermeneutic circle, basic version (Alvesson \& Sköldberg, 2011, p. 212)

My field notes and transcribed interviews consisted of rich and comprehensive data, and to analyse the texts I used a combination of open and axial coding in the form of the constant comparative method, as described by Glaser and Strauss (1967) and further developed by Charmaz (2014). To ensure coherence during this process, I found it necessary to adopt a hermeneutic approach to the analysis. Hence, I used a reflexive methodology from parts to a whole and vice versa, according to the basic version of Gadamer's $(1960,1989)$ "hermeneutic circle" (Alvesson \& Sköldberg, 2011). In this process of meta-perspective analysis, I consciously used my preunderstanding as a professional plumber, TVET teacher, and participator as an inside researcher, moving back and forth between pre-understanding and new understanding (Alvesson \& Sköldberg, 2011).

\section{Plumbing and Training at the Construction Site}

At the time of my fieldwork, the plumbers and apprentices built technical rooms and pipe systems for radiators, underfloor heating, water and wastewater systems, snow melting systems and underground main water and sewage installations in four apartment buildings. The plumbing manager and the team leader both participated in weekly progress meetings with the other company managers and the site manager. On an everyday basis, the team leader was in charge of and cooperated with the plumbing manager, the site manager, and the plumbers. All the plumbing companies in this study were members of a training agency and had long traditions of apprenticeship training. The analysis shows that training is important within 
the community of plumbers, and that the plumbers consider the young apprentices as pivotal participants and future colleagues. The analysis reflects how the plumbers really care about the way they treat the apprentices, and that the time they "invest" in the training soon will pay off in terms of both the work and the work environment:

If you don't care about the training, they [the apprentices] will never learn the difference between a good and a bad job. The earlier he or she learns, the earlier the training will pay off. There is no reason to shout and yell. No one makes mistakes on purpose. If they feel they are safe and accepted, they learn faster. You get what you give and if you treat them well, then it is possible to have a good working environment. If you are going to work as a plumber for many years, the environment is important. And, you never know, they may be your colleagues for the rest of your career. In a few years, they even may be your boss. (Plumber)

As newcomers, the youngest apprentices are often responsible for smaller and sometimes trivial tasks, such as drilling, picking up equipment and tidying up the storage areas, or preparing for a specific task such as carrying the necessary pipes, fittings and tools. During small and repetitive jobs, the apprentice must concentrate on the specific task. As a side effect, they become familiar with routines and rules and learn to interact and communicate with the plumbers and other workers on site. During my fieldwork, I watched how the youngest apprentice was doing a specific monotonous job for three weeks, and in the interview I asked him how he felt about that job: "Well, someone has to do it. Everything you do here at the construction site is important" (Apprentice). The feeling of being an active and significant participator in the plumber's community of practice gave a sense of affiliation and meaning. Doing real work and having the ability to plan and make one's own decisions stimulated feelings of responsibility and freedom:

At school, the teacher decided everything. As a student, you can't decide anything. And during breaks the teacher goes to the staff room and the students disappear in all directions. Here at the construction site, we decide a lot and we are together all day. (Apprentice)

Responsibility also triggered the apprentice's desire to be accepted by the plumbers. Because they were responsible for their own work tasks, the results depended on their own efforts, and the apprentices worked hard to deliver a good result. According to Merleau-Ponty (2002) and Dewey (1916), being an observer is quite different from being an active participant. Hence, in a peripheral role, the result is not that important. As a responsible actor however, the result depends on one's own efforts and ability to achieve it. If the result of the apprentices' work measures their ability to be plumbers, the apprentices may feel that their future career and their position in the community depend on their results. Hence, they do what 
they can to influence the direction of their work (Dewey, 1916; Illeris, 2006, 2015). When the task is completed, fear of failure is replaced by the sense of accomplishment and motivation. Through interacting and working side by side with the plumbers, the apprentices learn to plan a work task and to keep to a deadline, they gain self-confidence, grow muscles, attain manual dexterity and become familiar with the constitution of the community of plumbers. They also acquire knowledge about a broad spectrum of issues such as politics, society and family life, and gradually attain a professional and social position (Billett, 2001, 2016; Jordan, 1989; Wenger et al., 2002). In accordance with Lave and Wenger's (1991) theories of situated learning, the analysis of my field notes confirms the genuine impact the plumber's community had on being on the inside, as apprentices, with respect to the plumber's language and behaviour, their traditions of planning and doing work, and how they cooperated with other workers, managers and customers (Willis, 2013).

Every morning the plumbers gather in the plumbers' main depot in the middle of the site. Over a cup of coffee, they discuss and plan their day and the ongoing plumbing work. New information from the site management means that the schedule and current plans need correction. The analysis in this study shows that changes, delays and lack of - or wrong information lead to great frustration among the plumbers. On the one hand, when the plumbers put professional pride into their work, it feels demotivating when their efforts and their work are treated solely as capital:

They [the management] discuss and decide changes without informing me quite often. Also, they know that I work overtime to keep up the schedule. They know that every time I work overtime, I put my family and children on hold to finish the job. And when the next morning they tell me that I have to tear it all down and rebuild it because of some changes they decided days ago, then - I feel reduced to an object with no value, except for the value of the money I generate through my work. (Plumber)

On the other hand, the plumbers know that disruptions cost time and money that weaken the company's capital and reputation, which in turn affects the employees: "Of course, we want our company to do well. If the company does well, it means that our jobs and our future are safer" (Plumber).

Regarding coordination of their work and the workplace, the analysis shows that the plumbers take care of much more than just the plumbing. The blueprints always include interpretations of constructions, technical choices and use of materials and equipment, and my findings support Fear et al.s (2003) assertion that "real people engaging in real work" fosters valuable connections between theory and practice. Different ways of doing the same thing create variety in work tasks, and in addition to everyday plumbing tasks, the analysis shows that plumbers spend time discussing cost-effective and more functional ways to solve problems than suggested in the blueprint. In the actual context and situation, pipes, channels, and 
cable bridges look quite different from the blueprint, and technical complexity and the workers' professional choices affect real work. Billett argues that individuals can utilise what they know, what they can do, and what they value and thereby not only remake, but also transform their occupational practices (Billett, 2016). Through my fieldwork, I observed how skilled workers at the site communicated and managed to avoid upcoming obstacles, collisions, and delays as a natural part of their plumbing tasks.

\section{$7 \quad$ Learning and Training at the Training Agency}

The training agency was run by a vocational teacher with a background as a plumber and plumbing engineer. During my year of observations, the apprentices worked on key tasks in sanitary and heating - both comprehensive and complex - in order to recreate and identify real-world situations where the apprentices could practice using tools and materials, as well as develop professional rationale and language. To plan the practical tasks, the apprentices had to learn plumbing theory such as calculations and drawing, and - to understand the consequences of their drawings and calculations, they had to build the pipe systems. While the apprentices worked in groups, they were free to use both the classroom and the workshop. In TVET school, theory and practice are often referred to as separate dimensions. Dividing comprehensive work tasks into different subjects and teaching theoretical and practical content in different arenas and at different times often leads to a lack of coherent understanding and learning. By separating theory from practice, there is also a risk that the theory lessons may become more general, less situated, and less related to real work (Hiim \& Hippe, 2001; Hiim, 2013; Lensjø-Alvin, 2011; Spetalen et al., 2014). The analysis of my field notes indicates that misunderstandings between theory and practice are often revealed through practice. To identify, clarify and resolve problems and mistakes during everyday work, plumbers communicate through sketches and in a professional language based on key words and functional literacy from sanitary and heating technology. Just as important are linguistic expressions referring to unwritten knowledge in plumbing, containing occupational culture, history, and situated experience from professional practice in plumbing. As the apprentices in this study switched between working in plumbing companies at the site and once a week training at the training agency I observed how they quickly developed both a plumbing rationale and a professional plumbing language. While they worked in groups at the training agency, they were able to use their own language to discuss and compare use of materials, work tasks, and situations from their respective work experiences on site. With younger and less experienced peers, they could easily try out, start over and talk about ideas and thoughts they felt were difficult or impossible to talk about with the plumbers: 
It's exciting and very useful to meet others at your own level. It gives me confidence, because when we work in groups we open up and dare to speak, we try out and discuss what we mean and the things we have learned on site. We dare to say what we think and talk about different ways to do things. (Apprentice)

At first, the apprentices fumbled in both plumbing and professional communication. To be able to communicate at work, they tried to explain difficult situations by pointing or using informal language and "replacement words" like "that thing". After a few weeks, it was obvious how they had changed their vocabulary and more often used professional expressions as a natural part of their communication. At the training agency the TVET teacher introduced them to key words and professional terminology along with basic principles of water, sewage, and heating systems. To unite theory and practice, the TVET teacher always repeated relevant theories and continuously encouraged the apprentices to explain and discuss the functions of materials, such as valves and pumps in the pipe system, in their own words. While the apprentices worked on plumbing tasks in the workshop, the teacher moved between the groups and encouraged the apprentices to describe what they were doing and asked them the names of pipes and parts:

We meet once a week at the training agency. Every time, I start by repeating what we did last week. Then I introduce them to something new: technical drawings, regulations or plumbing theory. Always related to practice. I explain and then I want them to repeat by using their own words. For instance, what is a collection pipe and why do we need sewer ventilation? How do we know the difference between storm water pipes and sewage pipes in the ground? What consequences will it have if you connect sewage pipes to a storm water system? Every time we repeat, they remember a little more. When they begin to understand basic terminology and how things relate to words, they get an 'aha-moment'. Pieces are falling into place and suddenly they have gained an insight they can benefit from in several contexts and situations. Repeating and cramming. They are learning key words and plumbing terminology and using them in practice to explain work, things and functions. (TVET teacher in training agency)

Most skilled workers, like a plumber, can recognise phenomena related to situations and contexts, theories and regulations as well as skills, techniques, and procedures. To develop a professional language and to be able to put one's knowledge into words is a complex and time-consuming process for the apprentices. Yet analysis of the interviews shows that the plumbers emphasise the importance of developing a professional language and rationale. To be a professional plumber means you can discuss certain situations with managers and the architect and thereby are able to interact, influence, and improve your own work. The teacher's methodical repetition and use of terminology relate to the apprentice's work tasks at the training agency, which in turn reflect core tasks in plumbing. At the training agency, ter- 
minology and plumbing rationale become an increasing part of the apprentices' reflections in and on practice (Schön, 2009). Back at the construction site, the apprentices recognise details in work as well as terminology and language in the plumber's daily discussions in and on their actions and work tasks. One of the apprentices described how relevant content in practice and theory at the training agency made it easier to remember corresponding situations at the construction site, and how training and work emerged as holistic. Despite switching between two very different arenas, the apprentices expressed the feeling of being inside the same practice:

Here at the training agency, we have time to try and to fail. The teacher is good at explaining things. You need to be 'alert'. And when you're able to connect theory to real practice, it's easier to understand. When we can connect theory to our practice here in the workshop, which we recognise from the construction site, then I understand a lot more. Things we have done at the construction site, and then we do the same things here at the training agency. Then, I recognise it and understand why we did this and not that. (Apprentice)

\section{Interaction and Communication in the Community of Plumbers}

Analysis of the field notes shows that the plumbers establish a professional and social environment based mainly on plumbing and on site questions concerning plumbing and work, on the ability to solve practical problems and to investigate, discuss and rationalise why things must be like this and not like that, and to construct mutual knowledge within the community of plumbers. How the plumbers articulate, visualise through sketches, and design their process within their community at the construction site is in accordance with Schön's (2009) theory of reflective conversations about the situation and the context. Personal proficiency and experience in plumbing are highly valued within the community of plumbers. However, the older plumbers I met during my fieldwork never drew attention to their own knowledge or experience directly, nor expected any special position or treatment in the community of plumbers. On the contrary, they often spoke in a low voice. Every lunch hour, the plumbers started their break by updating each other on their progress. If needed, the plumbers drew sketches while depicting the problem and the situation. The plumbers often referred to similar situations that made it possible to compare and negotiate the current situation by telling stories.

After some weeks at the construction site, I observed the plumbing manager trying to figure out why a thermoblending valve was refusing to let hot water into the circulation pipes. As the plumber's depot for materials was located near the hot water central, the plumbers 
observed how the manager tried to solve the problem by opening and closing different valves, stopping and starting the pump, and checking if the temperature changed. Repeatedly he studied the blueprint and compared and watched every single part of the manifold. During lunch, the manager showed up at the plumbers' table, presented the problem and asked for their opinions. The younger plumbers had several suggestions, but the manager had already tried them all, - without success. Then the oldest plumber said quietly:

Well, I have found a couple of times that if the lockable unions connected to the thermoblending valve have been replaced with non-original unions, the non-return component inside the union may come loose and fly into the pipe. When they're stuck inside the pipe, they stop the water from flowing. (Plumber)

At that moment, everyone around the table understood that the plumber was sharing experienced knowledge which otherwise would be impossible to guess or to discover by watching the pipes, reading textbooks, manipulating algorithms or studying routines or definitions they had acquired with apparent competence in school. There and then, they revealed that they had no idea how to deal with this problem. According to Brown et al. (1989), people who use tools and materials build an increasingly rich implicit understanding of the world in which they use them, and of the tools and materials themselves. Learning how to use a tool or understanding how fittings and pipes sometimes construct "invisible" or unforeseen problems inside the pipe system involves far more than can be accounted for in a set of rules.

Quite often, the plumbers told vocational stories in connections with plumbing problems on site. By using professional language and drawings to explain and compare complex situations, they shared experiences and exchanged and constructed mutual knowledge about plumbing. By analysing my field notes and transcribed interviews transversely, a deeper pattern within the plumbers' communication emerged. In addition to providing rich and important data, the stories included specific variations and standards the plumbers could use to create analytical perspectives on their own practice. In their subsequent discussions, they separated and defined what was happening in the data (Charmaz, 2014). The vocational stories had comparable perspectives that helped the plumbers to organise, delineate, and capture the meaning of specific situation and hence to identify problems. By intuitively following Charmaz' (2014, p. 120) code for coding, the plumbers used several approaches to compare actual themes and gerunds. By analysing relevant stories, adhering closely to the data and defining the actions on which they rested, they compared data with data, recognising tacit assumptions, and crystallising the significance and relevance of actions and meanings (Charmaz, 2014). In order to find similarities and differences, the plumbers compared incident with incident, action with action, location with location, material with material, and time with time, all based on a multitude of implications that could have a bearing on the specific case. Using comparative methods, they moved in circles from preunderstanding to understanding 
and from parts to the whole - and the plumbers' analyses took the form of a hermeneutic circle (Gadamer, 1960, 1989). According to Alvesson and Sköldberg (2011), the aim of hermeneutic processes is to search for and find meaningful signs within a written or oral text, a drawing, picture or social action, signs that may affect and enrich the pattern of interpretation during the dialogue and the hermeneutic process. Hence, while the plumbers' stories were critically discussed and translated into new understanding, the conclusion always led to action where the plumbers tested, adjusted, and reconstructed the problem (Alvesson \& Sköldberg, 2011; Charmaz, 2014; Schön, 2009). In addition to professional development in such hermeneutic processes, Lave and Wenger (1991) emphasise how vocational stories help newcomers to understand the community's culture and history. Furthermore, by sharing experiences through specific stories, the plumbers generated mutual, professional knowledge across different levels of skills. By listening to the plumber's discussions and professional stories, the apprentices learned how the plumbers used drawings and expressions, how they talked, listened and argued, and how their world was socially and professionally constituted (Illeris, 2006, 2015; Lave \& Wenger, 1991; Wenger, 1998).

\section{Concluding Discussion}

In this study I followed apprentices and plumbers for one year of the work-based part of Norwegian TVET, which included three construction sites and one training agency. The analysis presents nuanced depictions of the apprentices' and plumbers' everyday life, and through stories of young apprentices' individual learning processes the analysis illustrates how interaction within communities of craftsmen can consist of a prominent culture for sharing knowledge in order to solve problems, but also in order to create mutual understanding. This study shows how apprentices and experienced plumbers develop tacit knowledge and skills through their involvement with relevant things and situations, and how they share their ability and professional experiences through drawings and storytelling, as active participants inside their community of practice. Learning in plumbing has little to do with imitation, and more to do with the individual's embodied perceptions of things and how plumbing requires time to learn through interaction and communication as essential parts of learning and work. Inside practice, the plumbers are close to materials and systems on construction site, where pipes, cableways and building structures look different from the plan and the progress on paper. This study shows examples of holistic and relevant education and training in a training agency combined with practice in a community of plumbers at the construction site. The analysis reveals the complexity in learning a profession that is based on interdependence between practical and theoretical knowledge. Despite all the differences between the training agency and the construction site, the analysis shows that the apprentices in this study experience that they are totally within the same practice of plumbing. To be within the same practice 
depends on the extent of recognition in the learning content and the ability to be considered as a professional participator. To be considered a professional participator in a community of professionals is based on a deep understanding and acceptance of the constant need to try out, fail and start over and at the same time be able to watch, listen and discuss professionally with peers, plumbers and other professionals. The sense of achievement and personal growth breeds professional pride and has a strong impact on the learning process. The analysis shows that plumbers do more than plumbing, and that their work requires significant local knowledge as well as plumbing and construction knowledge. Through reflection in and over work the plumbers investigate personal epistemologies and solve problems as a natural part of their work (Billett, 2016; Schön, 2009). By drawing sketches and telling relevant vocational stories, the plumbers bring rich, comparative data into the ongoing situation. Through interpretation, the plumbers analyse, discuss, test out and construct new, mutual knowledge across skill taxonomies (Alvesson \& Sköldberg, 2011; Charmaz, 2014; Lave \& Wenger, 1991; Schön, 2009).

\section{References}

Agrosino, M. V., \& Mays de Pères, K. A. (2000). Rethinking observation from method to context. In N.K. Denzin \& Y.S. Lincoln (Eds.), Handbook of Qualitative Research (2nd ed., pp. 673-702). Sage.

Alvesson, M., \& Sköldberg, K. (2011). Tolkning och reflektion [Interpretation and reflection]. Student litteratur AB.

Billett, S. (2001). Learning in the workplace: Strategies for effective practice. Allen \& Unwin.

Billett, S. (2006). Work, change and workers. Springer.

Billett, S. (2008). Emerging perspectives of workplace learning. Sense Publishers. https://doi-org.ezproxy.hioa.no/10.1163/9789087906450

Billett, S. (2014). Learning in the circumstances of practice. International Journal of Lifelong Education, 33(5), 674-693. https://doi.org/10.1080/02601370.2014.908425

Billett, S. (2016). Apprenticeship as a mode of learning and model for education. Education \& Training, 58(6), 613-628. https://doi.org/10.1108/ET-01-2016-0001

Brown, J. S., Collins, A., \& Duguid, P. (1989). Situated cognition and the culture of learning. Educational Researcher, 18(1), 32-42. https://doi.org/10.3102/0013189X018001032

Charmaz, K. (2014). Constructing grounded theory (2nd ed.). Sage.

Dewey, J. (1916). Demokrati og uddanning [Democracy and education]. Forlaget Klim.

Dreyfus, H., \& Dreyfus, S. (2012). Fem stadier af færdighetdstilegnelse - fra nybegynder til ekspert [Skill Acquisition]. In K. Illeris (Ed.), 49 tekster om loering (pp. 423-436). Samfundslitteratur.

Eikeland, O. (2015). The general in vocational pedagogy. In O. Eikeland, H. Hiim \& E. Schwencke (Eds.), Perspectives in vocational pedagogy (pp. 17-21). Gyldendal Akademisk.

Fear, F. A., Bruns, K., Sandmeyer, L., Fields, A. M., Buhler, S., Burnham, B., \& Imig, G. (2003). Experiencing engagement: Stories from the field. Journal of Higher Education Outreach and Engagement, 8(1), 59-73. https://openjournals.libs.uga.edu/jheoe/article/view/621

Gadamer, H.-G. (1960). Truth and method. Sheed \& Ward. 
Gadamer, H.-G. (1989). Destruction and deconstruction: The Gadamer-Derrida encounter (D. P. Michelfelder \& R. E. Palmer, Eds.). State University of New York Press.

Gamble, J. (2001). Modelling the invisible: The pedagogy of craft apprenticeship [Studies in continuing education]. Taylor \& Frances Group, 23(2), 185-200. https://doi.org/10.1080/01580370120101957

Gibson, G. (2016). Experience, education and subjectivity. A comparison of John Dewey's and Maurice Merleau-Ponty's conceptions of experience and their implications for education [Master's thesis, Queens University]. https://hdl.handle.net/1974/15207

Giddens, A. (1993). New rules of sociological method: A positive critique of interpretative sociologies. Polity Press.

Glaser, B. G., \& Strauss, A. L. (1967). The discovery of grounded theory: Strategies for qualitative research. Aldine Transaction.

Hastrup, K. (2010). Feltarbejde [Fieldwork]. In S. Brinkmann \& L. Tanggaard (Eds.), Kvalitative meto$\operatorname{der}$ (pp. 55-80). Hans Reitzels Forlag.

Hiim, H., \& Hippe, E. (2001). A utdanne profesjonelle yrkesutøvere [To educate professional practitioners]. Gyldendal Norsk Forlag.

Hiim, H. (2013). Praksisbasert yrkesutdanning: Hvordan utvikle relevant yrkesutdanning for elever og arbeidsliv? [Practice based VET: How to develop relevant VET for students and working life?]. Akademisk Forlag.

Illeris, K. (2006). Loring [Learning]. Roskilde Universitetsforlag.

Illeris, K. (2015). The development of a comprehensive and coherent theory of learning. European Journal of Education, 50(1), 29-40. https://doi.org/10.1111/ejed.12103

Jordan, B. (1989). Cosmopolitical obstetrics: Some insights from the training of traditional midwives. Social Science \& Medicine, 28(9), 925-944. https://doi.org/10.1016/0277-9536(89)90317-1

Lave, J., \& Wenger, E. (1991). Situated learning: Legitimate peripheral participation. Cambridge University Press.

Lensjø, M. (2017). Loring og opploring i rørleggerfaget. En etnografisk studie av fag- og yrkesopploering i opploeringskontor og på byggeplass [Learning and training in plumbing. An ethnographic study of VET in training office and at the construction site] [Doctoral dissertation, Roskilde University]. https://rucforsk.ruc.dk/ws/portalfiles/portal/59787042/Marit_Lensj_._Ph.d._avhandling_2_.pdf

Lensjø-Alvin, M. (2011). En masteroppgave om hvordan struktur og styringsdokumenter $i$ Kunnskapsløftet påvirker gjennomføringen og innholdet i rørleggerutdanningen [Structures, content and implementation of the plumbing education][Master's thesis, Akershus University College].

Merleau-Ponty, M. (1994). Phènomènologie de la perception [Phenomenology of perception]. Routledge Classics.

Merleau-Ponty, M. (2002). Phenomenology of perception (2nd ed.). Routledge. https://doi. org/10.4324/9780203994610

Nore, H. (2015). Re-contextualizing vocational didactics in norwegian vocational education and training. International Journal for Research in Vocational Education and Training, 2(3), 182-194. https://doi.org/10.13152/IJRVET.2.3.4

Norwegian Directorate of Education and Training. (2020). Satser loerlinger, praksisbrevkandidater, loerekandidater og kandidater for fagbrev på jobb 2020 [Apprenticeship grants, internship candidates, apprenticeship candidates and candidates for trade certificates at work 2020]. https://www. udir.no/om-udir/tilskudd-og-prosjektmidler/tilskuddssatser/forelopige-satser-larlinger-praksisbrevkandidater-larekandidater-og-kandidater-for-fagbrev-pa-jobb---2020ny-side/ 
Polany, M. (1966). The Tacit Dimension. Routledge \& Kegan.

Ringer, A. (2013). Researcher-participant positioning and the discursive work of categories: Experiences from fieldwork in the mental health services. Qualitative Studies, 4(1), 1-20. https://doi.org/10.7146/qs.v4i1.8126

Schön, D. A. (2009). The reflective practitioner: How professionals think in action (4th ed.). Forlaget Klim.

Sennett, R. (2009). The craftsman. Penguin Books Ltd.

Spetalen, H., Johansen, E. M., \& Johansen, K. L. (2014). Kvalifisering til læretid - Ikke bare et spørsmål om teori eller praksis i skoleopplæringen [Qualification to apprenticeship - Not only a question about theory or practice in school]. Nordic Journal of Vocational Education and Training, 4(1), 1-11. https://doi.org/10.3384/njvet.2242-458X.14v4i1a2

Tesfaye, M. (2013). Kloge honder - et forsvar for håndverk og faglighed [Wise hands - a defence for craftsmanship and professionalism]. Gyldendal.

Van der Geest, S., \& Sarkodie, S. (1998). The fake patient. A research experiment in a Ghanaian hospital. Social Science \& Medicine, 47(9), 1373-1381. https://doi.org/10.1016/S0277-9536(98)00179-8

Wadel, C. C. (2016). Feltarbeid i egen kultur [Fieldwork in one's own culture]. Cappelen Damm akademisk forlag.

Wenger, E. (1998). Communities of practice. Learning, meaning and identity. Cambridge University Press.

Wenger, E., McDermott, R., \& Snyder, W. M. (2002). Cultivating communities of practice: A guide tomanaging knowledge. Harvard Business School Press.

Willis, P. (2013). "Practice story exchanges" and their creative invitation to informal learning. International Journal of Adult Vocational Education and Training, 4(3), 57-66. https://doi.org/10.4018/ ijavet.2013070106

Whyte, W. F. (1981). Street corner society (3rd ed.). The University of Chicago Press.

Yang, C. (2013). Telling tales at work: An evolutionary explanation. Business Communication Quarterly, 76(2), 132-154. https://doi.org/10.1177/1080569913480023

\section{Biographical Note}

Dr Marit Lensjø is a post doctor at the Institute of Vocational Teacher Education at Oslo Metropolitan University in Norway. Her research interests focus on Vocational Education and Training in Upper Secondary School, in Training agencies and Training Enterprises. 